\title{
Magdalena Bełza-Gajdzica'
}

\section{Educational Space of a Learner with Disability in the Context of Infrahumanization of "Outgroups"}

\begin{abstract}
The study is aimed at presenting the educational space of a disabled learner within the category of infrahumanization - social categorizing into "ingroups" and “outgroups”. The presented issues comprise educational space, three functioning forms of education, the phenomenon of infrahumanization and the common group identity. Disabled learners' functioning within a class is presented in: mainstream school (where the dominating group consists of learners without disabilities), integrated school (where categorization of learners is shaped in the way offering more chances to the disabled), and special school (a segregationbased form). Two dimensions of the discussed phenomenon of infrahumanization are indicated - heterogeneousness, which enhances attitudes of acceptance and understanding within a class group (micro-dimension) and its more serious social consequences (macro-dimension).
\end{abstract}

\section{Keywords:}

educational space, disabled learner, infrahumanization, relations, group domination

\section{INTRODUCTION}

The article is aimed at discussing the phenomenon of infrahumanization of "others", in this study identified as disabled learners. The starting point for considering infrahumanization is the educational space viewed as a meeting place of two worlds - of learners with and without disability - the world which forms a particular social structure. In practice, every social structure (also school) leads

1 Department of Special Education, Faculty of Ethnology and Education, University of Silesia, Cieszyn, Poland.

E-MAIL: belzamagda@interia.plＯRCID: 0000-0002-1316-6689 
to diversification of roles and statuses (Gajdzica, 2010). This might result in the divisions into the own (ingroups) and the others (outgroups). The phenomenon of infrahumanization, strictly related to this diversification, is a broad issue. In the further part, it will be referred only to the types of educational space which correspond to three forms of education offered to disabled learners. This imposes the structural order applied in the study.

The educational space of disabled learners is a problem frequently undertaken in current discussions in the field of pedagogy (mostly in special education) - the conducted research into their functioning, in particular (separating, integration, inclusive) educational forms, shows the multisided and complex nature of these issues. Infrahumanization of "others", which is the major effect of social categorization into "ingroups" and "outgroups” (Leyens et al., 2000), may become useful in explaining classroom relations and in broadening the perspective of seeking the sources of difficult situations taking place in educational processes within this group of learners. Space, as an ambiguous notion, can be considered from the standpoint of different scientific disciplines (Lewicka, 2012). For the needs of this study, it is understood as a way of interpretation, as a human construct created by individuals and groups, as well as an abstract idea, a property of solid matter or of the natural developmental environment (cf. Jałowiecki \& Szczepański, 2006). In a closer perspective, space is treated here as the educational space of a disabled learner, which in Poland comprises three basic forms: mainstream, integrated and special schools (Bełza, 2011), compliantly with the triple division of the educational system into the segregated, partially segregated and non-segregated form. The last is often referred to as inclusive education (cf. Pańczyk, 1997; Gajdzica, 2008; Zamkowska, 2009). Educational space consists of many dimensions, however, due to the limitations imposed by the publishing framework, the space of school class (constituting a specific centre of institutionalized education) will be focused on in this study. This does not imply complete omission of other spaces which constitute the context of school class space. It shows the complexity of mutual relations and attitudes of people with disabilities or special developmental and educational needs with non-disabled people, as well as their considerable importance for effective rehabilitation, satisfying education and self-determination in an autonomously created biography (Janiszewska-Nieścioruk \& Zaorska, 2014).

Considering the phenomenon of infrahumanization in these three forms is interesting due to the prevalence of different learner groups (the number of learners with and without disability) in class, the relations between them, and the approach to the education of disabled learners in general. Another important goal of the study is an attempt at showing special school in the context of its advantages, 
which seems significant in the light of common trends towards inclusion and vast criticism of segregating educational practices.

\section{TERMINOLOGICAL EXPLANATIONS}

The space of school class is a specific social micro-environment, in which a specific climate comes into being, determined by the general social context, the heterogeneousness of the group, organizational and legal factors, methodological rules and personality traits of participants in the interaction (Gajdzica, 2010). The notion of school class refers, firstly, to a group of learners educated in the same school room, implementing the same syllabus, and representing the same level of educational carrier. Secondly, this notion can refer to a place, a classroom, a room where school education is conducted (Okoń, 2007). Unfortunately, in the context of teaching disabled learners, these definitions turn out to be insufficient, because frequently learners with disabilities implement a different syllabus, are on different levels of school career and have started school later (Gajdzica, 2011). As infrahumanization is strictly associated with the feeling of group identity, it is more justified to apply the definition which says that school class is a group of learners who influence each other, differ in roles and positions, and have a common system of values and norms regulating their behaviour in important class matters (Łobocki, 1974).

A disabled learner is someone who can have difficulties with learning or/and socialization due to lowered psychophysical ability and who might need special support to improve their: health condition and general fitness, the capability of the organs which are impaired, school learning possibilities and learning achievements, as well as social independence in life activities, games, peer classes and other civilizational-cultural situations (Maciarz, 1992). Depending on the applied concept, this notion can be grounded in the medical aspect (which dominated the way of thinking about the disabled learner for many years), viewed in the context of special educational needs (especially visible in psychological concepts), approached through special organization of mainstream needs (where the assumption is made not to differentiate learners' needs and special support is provided to the learners with difficulties in fulfilling the mainstream curriculum), defined through the constructivist perspective (based on the assumption of constructing the image of a disabled learner in the course of interactions taking place in class (Gajdzica, 2010). In the context of the discussion on infrahumanization, especially on shaping the common group identity, the last standpoint seems the closest. The construction of this image may stem from categorizing a particular person as belonging to the "ingroup or "outgroup". 
Yet, human perception is not free of categorization mistakes (Harris \& Fiske, 2012). Infrahumanization combines both the favouring of the own group and the derogation of the alien one (Leyens et al., 2003). However, it has been confirmed that the effect of infrahumanization of "others" is independent from the effect of widely known and studied favouring of the "own". Infrahumanization is not a popular issue in pedagogy, although the related phenomenon of dehumanization is relatively often discussed in special education. In contrast to dehumanization, which totally negates humanity of others, infrahumanization is a tendency to categorize people as the "own" or the "alien". It directly concerns affection and distinguishes between primary emotions (e.g., sadness) and secondary - social, complex - emotions (e.g., expiation). Complex (secondary) emotions are attributed to others to a smaller extent than to the own (Leyens et al. 2000, 2003, as quoted in: Harris \& Fiske, 2012). The basic effect of infrahumanization - attributing these uniquely human emotions to other groups to a smaller extent than to the own group - indicates that others are perceived as less human (Haslam, Bain, Bastian, \& Loughnan, 2012). This theory broadened the previous way of thinking about dehumanization, which earlier had been limited to conflict situations involving the co-occurring extreme suffering and cruelty, and has pointed to several qualities of this phenomenon. Firstly, it takes place in all cases where there are groups. Secondly, infrahumanization does not mean that members of other groups are perceived as not human, but rather suggests attributing the uniquely human features more to the own groups than to the alien ones. Thirdly, infrahumanization has turned out to be an independent process from the negative attitude to others, which means that possessing both positive and negative secondary emotions by the members of outgroups is denied. Fourthly, this phenomenon often takes place in a hidden way - people are frequently unaware that they evaluate the humanity of the own and of the others differently. Finally, what seems most important in the context of educating disabled learners is that the effect of infrahumanization enables predicting different behaviour towards the members of the own and the alien group. This has a lot of significance in predicting the behavioural intentions in many important intergroup contexts (Vaes et al., 2012).

\section{A DISABLED LEARNER'S SPACE IN MAINSTREAM SCHOOL VERSUS THE PHENOMENON OF INFRAHUMANIZATION}

The first space discussed in this study is associated with the currently common idea of inclusion or inclusive education. It is implemented by the opening of mainstream schools to accepting and educating possibly all children, despite 
the difficulties and differences which they experience (Żółkowska, 2007). This reveals an interesting field for observing the phenomenon of infrahumanization. As many studies confirm, the processes of homogenization pave the way for hasty generalizations - stereotypes, which activate as the first ones at the moment of contact with a newly met person (Kofta, 2004). Inclusive class in mainstream school generates the space where the world of fully able learners and the microworld of disabled learners meet. This is a situation in which a group of disabled learners constitutes a minority and is usually dominated by learners without disabilities. A disabled learner who appears in class is categorized on the basis of the so called prime - a stimulus which appears just before another, the destined stimulus (Śpiewak, 2005). What seems to be noticed at first is the stigma which is the person's characteristic feature, e.g., a white walking stick, a hearing aid, peculiar appearance. It can be also a document certifying the need for special education, which automatically categorizes the learner to the group of "aliens". In the context of infrahumanization, the situation of a disabled learner in mainstream school is the least favourable. The lack of awareness of both teachers and learners as well as the lack of interest in disabled learners' needs pushes them into the margin, causes their isolation, and can lead to their discrimination. The research shows that these students function much worse in the role of a learner, due to their being rejected or stigmatized as incapable and helpless, and that their peer contacts are poor (Maciarz, 2000).

Infrahumanization, which enhances rejection, makes the situation of disabled learners unfavourable - the lack of acceptance by the peer group makes them apply a negative attitude to their community and school (Maciarz, 2000). Many years of experience shows that integration practices bring about the marginalization and stigmatization of disabled students (Chrzanowska, 2009).

\section{A DISABLED LEARNER'S SPACE IN INTEGRATED SCHOOL VERSUS THE PHENOMENON OF INFRAHUMANIZATION}

The second space of a disabled learner's education is the space of integrated class. It creates different circumstances than in the case of previously discussed space, because the presence of disabled learners is the preliminary assumption here. The theoretical attitude of both groups should be aimed at concordant coexistence of both groups. Although learners without disabilities constitute the bigger group, neither of the groups should dominate. Infrahumanization of the disabled results in the reactions which involve instinctive attributing a particular stereotype, acti- 
vated by the prime and inducing a reaction of automatic classification of these people to the outgroup and the ingroup (or, often colloquially called, "integrated" and "normal"), depending on the identity of a person entering the interaction. A fully able person will classify a disabled one as “alien” (integrated) and inversely.

The foundation of integrated education is the respect for differences among people and for the dignity of every person (Lis-Kujawski, 2010). This makes integration enhance shaping a positive image of disabled people and increases the chances for categorizing the disabled in the perspective of the own group, not of the alien one. The list of differences is long (Oleńska-Pawlak \& Bombińska-Domżał, 2012) but, owing to this, new systems of categorization can be built. Through being together and the undertaken activities, integrated education should offer better possibilities of changing the perception of "others" to the "own". Unfortunately, it often takes place that lack of chances in the peer competition concerning educational achievements and social positions in group makes disabled learners exist on the margin of the class community. This increases the distance between them and their properly developing peers and enhances infrahumanization of disabled learners as aliens. Despite the requirements of collaboration, mutual respect and mature social attitudes imposed on both groups (Lis-Kujawski, 2010), even (most often only apparently) correct relations between learners with and without disabilities will not counteract the phenomenon of infrahumanization and attribution of less human qualities to the disabled without precise undertakings aimed at the rejection of stereotypical thinking and of treating the integrated class as one, not two groups (Szumski, 2006). Such correct relations are not enough to ensure the success of integration.

\section{THE PHENOMENON OF INFRAHUMANIZATION IN THE SPACE OF SPECIAL SCHOOL}

The space of special school or the segregated form is discussed as the last in this study. On one hand, it is considered to be the most discriminating and stigmatizing form of education, but on the other - in the aspect of the discussed phenomenon of infrahumanization, heterogeneousness seems to enhance the attitudes of acceptance and understanding within the class group. This is not an ideal situation without any drawbacks, such as isolation of the group and the categorization of particular learners as "others" after leaving the institution. However, it might be assumed that the phenomenon of infrahumanization in the space of special class does not exist, or if it exists - it takes place in a minimal degree, has a different nature, or is observed in regard to other people than peers (e.g., teachers, technical 
staff). Being with peers categorized as the "own" provides learners with the feeling of safety. Lack of co-existence with fully able peers brings about lack of experiences of categorization, which - however - takes place outside school. It turns out that an apparently positive situation might reduce the reality of the disabled (Prysak, 2014), who are provided with the conditions of acceptance and the feeling of safety through the heterogeneousness of the group. Still, at the same time these conditions do not allow for building this acceptance on the side of fully able peers, in this case - "others", who wait for the disabled in the society, outside the safe classroom space. Thus, the phenomenon of infrahumanization of others in the educational space of special school can be referred to two levels - the micro- and macro-scale. The ideal educational space of school, the micro-level, ensures counteracting both phenomena - infrahumanization and (often related) discrimination. Learners in a homogeneous group, in which there are no two groups (learners with and without disability), are protected by the categorization only to the ingroup. It is hard to find the problem of stigmatization or discrimination when most of the learners function on a similar level. The problem appears in the broader context, in the macro-scale, pertaining to non-school social space, where learners come back after classes and are forced not so much to categorizing but to being categorized by the environment in which they live. Being categorized as a disabled person often means the feeling of being worse, less valuable, rejected or laughed at.

\section{BUILDING THE COMMON GROUP IDENTITY}

Disability is a notion the defining of which depends on many factors, therefore it does not have an absolute character. Infrahumanization of the disabled as members of the "alien” group takes place in an affective, unaware way, as the first reaction to the occurrence of the earlier mentioned prime. Yet, defining disability, and first of all the categorization of a person into the outgroup, largely depends on social interactions between members of the society - between fully able people without contact with the disabled, between fully able people who have contacts with the disabled, and between the disabled themselves (cf. Bełza, 2016). Infrahumanization is a consequence of social categorization. An activated category enables indicating the group membership, but at the same time, it refers to the knowledge of particular structures - schemes or stereotypes (Chromiec, 2004).

Regardless of the space in which a disabled learner functions (whether this is a mainstream, integrated or special class), it is important to aim at building the common group identity. It consists in raising - in certain circumstances - the 
"others" into the rank of human dignity (Baran, 2004). Enriching the knowledge concerning other groups and showing that there are more things which join than separate the "own" group from the members of alien groups is the foundation of changes in education. Overcoming the assumption that disabled people belong to the group of "others", "aliens", "the different” should take place through modification of the degree of similarity between Me and representatives of other groups (Sadowska, 2005). The appearance of one superior category, resulting from the transformation of cognitive representations of the ingroup and outgroups, leads to impairing or disappearance of the consequences of social categorization. This is enhanced by the engagement of both groups in fulfilling the common goal (Sherif et al., 1961). When a change in the mutual perception of groups takes place, it is crucial to change the point of view of both the alien and the own group (Stangor \& Schaller, 1999). Such changes are facilitated by interactions between people with and without disabilities and the type of these interactions - whether the experiences are good for both sides, which will build a positive image of and attitude to a group perceived as alien, or the situation is reversed and, through bad experiences, the stereotypes will be perpetuated. A valuable strategy resulting in re-categorization is the strategy of cross-categorization. It involves considering the possibly biggest number of cognitively available attributes which distinguish more and more new and intercrossing groups of people. Creating a new "We" identity with the help of educational curricula is aimed to enhance the reflection that every person (with and without disability) belongs to many different social groups and that belonging to one group does not exclude belonging to another (Sadowska, 2005).

\section{CONCLUSIONS}

Regardless of a disabled learner's place in the current system of education, the phenomenon of infrahumanization takes place at all times. The presented discussion shows that it is significant for daily functioning of such a learner. Categorization, which a learner encounters, substantially influences the birth of some particular types of intergroup interaction that can enhance either socialization or segregation. As the research indicates, people attribute humanity to themselves to a larger extent than to others (Haslam, Bain, Douge, Lee \& Bastian, 2005). The mechanism taking place here is similarity (Vaes, Paladino, Castelli, Leyens, Giovanazzi, 2003), not the level of acquaintance (Cores, Demoulin, RodríguezTorres, Rodríguez-Pérez, Leyens, 2005) (cf. Harris \& Fiske, 2012). Being familiar with these mechanisms, it is important to take them into account in designing the 
educational process for disabled learners (regardless of the educational form) and to aim at the situation in which fully able learners will notice in their disabled peers a bigger number of similar qualities, allowing them for categorizing them into the own group, rather than differentiating qualities, categorizing them into the group of "others".

What was intentional in my study was starting with the discussion of the functioning of disabled learners in the classroom space in mainstream school (where "fully able" learners dominate) and moving on to the integrated school, where categorization applies a different shape and provides the disabled with more chances. Special school was discussed as the last one. It is widely thought to be the most discriminating and stigmatizing. However, in the aspect of the discussed phenomenon of infrahumanization, this becomes an argument promoting this form of education, because heterogeneousness is favourable for attitudes of acceptance and understanding within the group. On the other hand, it also results in broader social consequences. It is also worth emphasizing that this phenomenon will be different depending on the type of disability.

\section{References}

Baran, T. (2004). Zjawisko dehumanizacji w relacjach międzygrupowych: Znaczenie kategoryzacji społecznej, kooperacji i rywalizacji. In: M. Kofta (Ed.), Myślenie stereotypowe i uprzedzenia. Mechanizmy poznawcze i afektywne (pp. 117-137). Warszawa: Wyd. Instytutu Psychologii PAN.

Bełza, M. (2011). Szkolnictwo specjalne w Polsce - różne formy organizacji, In: S. Wrona, \& I. Fajfer-Kruczek (Eds.), Wsparcie instytucjonalne osób niepełnosprawnych w Polsce i Republice Czeskiej (pp. 24-42). Cieszyn: Wydawnictwo "ARKA".

Bełza, M. (2016). Ableism a zjawisko infrahumanizacji „obcych”. Terażniejszość - Człowiek - Edukacja, Vol. 19, No 2(74), pp. 77-87.

Bełza, M. (2015). Systemy edukacji osób umiarkowanie i znacznie oraz głęboko niepełnosprawnych intelektualnie (na przykładzie rozwiqzań w Anglii, Republice Czeskiej i Polsce). Katowice: Wydawnictwo Uniwersytetu Śląskiego.

Chromiec, E. (2004). Dziecko wobec obcości kulturowej. Gdańsk: Wydawnictwo GWP.

Chrzanowska, I. (2009). Zaniedbane obszary edukacji - pomiędzy pedagogikq a pedagogikq specjalnq. Wybrane zagadnienia. Kraków: Oficyna Wydawnicza „Impuls”.

Gajdzica, Z. (2008). W trosce o wielostronny rozwój ucznia. Kilka uwag o wyborze szkoły i formach realizacji obowiązku szkolnego dziecka z lekkim upośledzeniem umysłowym, In: Z. Gajdzica (Ed.), Wspólne i swoiste zagadnienia edukacji i rehabilitacji osób z upośledzeniem umysłowym (pp. 103-112). Sosnowiec: Wydawnictwo Humanitas.

Gajdzica, Z. (2010). Codzienność ucznia niepełnosprawnego - perspektywa badacza, In: M. Dudzikowa, \& M. Czerepaniak-Walczak (Eds.), Wychowanie. Pojęcia - procesy - konteksty. Tom 5 (pp. 161-184). Gdańsk: Wydawnictwo GWP. 
Gajdzica, Z. (2011). Sytuacje trudne w opinii nauczycieli klas integracyjnych. Kraków: Oficyna Wydawnicza "Impuls".

Harris, L.T., \& Fiske, S.T. (2012). Percepcja dehumanizująca - dowody z obszaru społecznej neuronauki. In: M. Drogosz, M. Bilewicz, \& M. Kofta (Eds.), Poza stereotypy. Dehumanizacja w postrzeganiu grup społecznych (pp. 227-271). Warszawa: Wydawnictwo Scholar.

Haslam, N., Bain, P., Douge, L., Lee, M., \& Bastian, B. (2005). More Human than You: Attributing Humanness to Self and Others. Journal of Personality and Social Psychology, 89(6), pp. 937-950. DOI: 10.1037/0022-3514.89.6.937

Haslam, N., Bain P., Bastian, B., \& Loughnan, S. (2012). Spojrzenie na dehumanizację. In: M. Drogosz, M. Bilewicz, M. Kofta (Eds.), Poza stereotypy. Dehumanizacja w postrzeganiu grup społecznych (pp. 196-208). Warszawa: Wydawnictwo Scholar.

Jałowiecki, B., \& Szczepański, M.S. (2006). Miasto i przestrzeń w perspektywie socjologicznej. Warszawa: Wydawnictwo Naukowe SCHOLAR.

Janiszewska-Nieścioruk, Z., \& Zaorska, M. (2014). Prowłączające zmiany w polskim systemie edukacji - nowe możliwości, ograniczenia i wyzwania. Interdyscyplinarne Konteksty Pedagogiki Specjalnej, 4 (pp. 9-28). DOI: 10.14746/ikps.

Kofta, M. (2004). Stereotypy i uprzedzenia a stosunki międzygrupowe. Stare i nowe idee. In: M. Kofta (Ed.), Myślenie stereotypowe i uprzedzenia. Mechanizmy poznawcze i afektywne (pp. 9-38). Warszawa: Wydawnictwo Instytutu Psychologii PAN.

Lewicka, M. (2012). Psychologia Miejsca. Warszawa: Wydawnictwo Naukowe SCHOLAR.

Leyens, J., Cortes, B.P., Demoulin, S., Dovidio, J., Fiske, S.T., Gaunt, R., Paladino, M.P., Rodrígues-Torres, R., \& Vaes, V. (2003). Emotional Prejudice, Essentialism and Nationalism. European Journal of Social Psychology, 33 (pp. 703-717). DOI: 10.1002/ejsp.170.

Leyens, J., Paladino, M.P., Rodrígues-Torres, R., Vaes, V., Demoulin, S., Rodrígues-Pérez, A., \& Gaunt, R. (2000). The Emotional Side of Prejudice: The Attribution of Secondary Emotions to Ingroups and Outgroups. Personality and Social Psychology, 31(4). (pp. 186-197). DOI: oi.org/10.1207/S15327957PSPR0402_06

Lis-Kujawski, A. (2010). Moje “ja” i szkoła integracyjna. Kraków: Oficyna Wydawnicza Impuls.

Łobocki, M. (1974). Wychowanie w klasie szkolnej. Z zagadnień dydaktyki grupowej. Warszawa: Wydawnictwa Szkolne i Pedagogiczne.

Maciarz, A. (1992). Uczniowie niepełnosprawni w szkole powszechnej. Warszawa Wydawnictwa Szkolne i Pedagogiczne.

Maciarz, A. (2000). Nadzieje i obawy zwiq̨zane z reforma szkolnictwa specjalnego. "Szkoła Specjalna”, 1, pp. 11-14.

Okoń, W. (2007). Nowy słownik pedagogiczny. Warszawa: Wydawnictwo “Żak”.

Oleńska-Pawlak, T., \& Bombińska-Domżał, A. (2012). Współpracować aby zaktywizować - jak organizować pracę w grupach i klasach integracyjnych (pp. 40-51). In: P. Majewicz, \& A. Mikrut (Eds.), Aktywizacja ucznia z niepełnosprawnościq w różnych obszarach jego edukacji. Kraków: Wydawnictwo Uniwersytetu Pedagogicznego.

Pańczyk, J. (1997). Pedagogika specjalna w Polsce u progu XXI wieku. In: W. Dykcik (Ed.), Pedagogika specjalna (pp. 85-102). Poznań: Wydawnictwo Uniwersytetu Adama Mickiewicza. 
Prysak, D. (2014). Od zredukowanej do poszerzonej rzeczywistości uczniów z głęboką niepełnosprawnością intelektualną - analiza działań edukacyjnych. Niepełnosprawność. Dyskursy pedagogiki specjalnej, 14, pp. 113-123.

Sadowska, S. (2005), Ku edukacji zorientowanej na zmianę społecznego obrazu osób niepełnosprawnych. Toruń: Wydawnictwo Akapit.

Sherif, M., Harvey, O.J., White, B.J., Hood, W.R., \& Sherif, C.W. (1961). Intergroup Conflict and Cooperation: The Robbers' Cave Experiment. Oklahoma: University of Oklahoma Press, Norman.

Stangor, Ch., \& Schaller, M. (1999). Stereotypy jako reprezentacje indywidualne i zbiorowe. In: C.N. Macrae, Ch Stangor, \& M. Hewstone (Eds.), Stereotypy i uprzedzenia. Najnowsze ujęcie (pp. 13-36). Gdańsk: Wydawnictwo GWP.

Szumski, G. (2006). Integracyjne kształcenie niepełnosprawnych. Warszawa: Wydawnictwo APS - PWN.

Śpiewak, S. (2005). Przez poznawczą dziurkę od klucza. O badaniu funkcjonowania umysłu w sytuacjach społecznych. In: M. Kossowska, M. Śmieja, \& S. Śpiewak (Eds.), Społeczne ścieżki poznania (pp. 191-214). Gdańsk: Wydawnictwo GWP.

Vaes, V., Paladino, M. P., Castelli, L., Leyens, J. P., \& Giovanazzi, A. (2003). On the Behavioral Concequences of Infrahumanization: The Implicid Role of Uniqueli Human Emotion in Intergroup Relations. Journal of Personality and Social Psychology, 85, (pp. 1016-1034). DOI: 10.1037/0022-3514.89.6.937.

Vaes, V., Paladino, M.P., Miranda, M.M.P. (2012). Dehumanizacja w procesach grupowych: funkcje i moderator (de)humanizacji grupy własnej i obcej. In: M. Drogosz, M. Bilewicz, \& M. Kofta (Eds.), Poza stereotypy. Dehumanizacja w postrzeganiu grup społecznych (pp. 166-195). Warszawa: Wydawnictwo Scholar.

Zamkowska, A. (2009). Wsparcie edukacyjne uczniów z upośledzeniem umysłowym w stopniu lekkim $w$ różnych formach kształcenia na etapie edukacji. Radom: Wydawnictwo Politechniki Radomskiej.

Żółkowska, T. (2007). Wybrane koncepcje edukacji integracyjnej. In: Z. Janiszewska-Nieścioruk (Ed.), Problemy edukacji integracyjnej dzieci i młodzieży z niepełnosprawnościq intelektualnq (pp. 43-54). Kraków Oficyna Wydawnicza Impuls. 